\title{
Performance of Nutritionally Optimised Millet Porridges as Complementary Food for Children from Low Socio-Economic Status Households in Bujenje County, Western Uganda
}

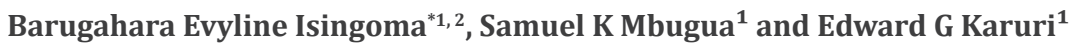 \\ ${ }^{1}$ Department of Food Science, Nutrition and Technology, University of Nairobi, Kenya \\ ${ }^{2}$ Department of Human Nutrition and Home Economics, Kyambogo University, Uganda
}

Received: January 17, 2018; Accepted: February 6 , 2018; Published: February 20, 2018

*Corresponding author: Barugahara Evyline Isingoma, Department of Human Nutrition and Home Economics, Kyambogo University, Box 1 , Uganda, Tel: +256782673038, Email: bisingoma@gmail.com

\begin{abstract}
Lack of proper complimentary foods continues to be a problem in many parts of the world, especially among low socio-economic status households. The main objective of this study was to evaluate the effect of optimised millet porridges on the nutritional status of moderately malnourished children. The study was a closed cohort study involving 93 moderately wasted children aged 7-36 months and their mothers/caretakers. Thirty two children recruited from Ntooma village centre were fed on traditional millet porridge as the control while 30 from Karongo and 31 from Kiryamyongo village centres were fed on millet porridges optimised with $7 \%$ moringa leaf powder and $17 \%$ pumpkin flesh powder respectively. Optimised millet porridges were fermented using lactic acid fermentation starter cultures. Anthropometric measurements, dietary assessments and morbidity patterns of children in the study were monitored for 4 months. One way ANOVA (Analysis of Variance) and Chi-square tests were used to analyse the effect of porridges on the nutritional status of children. In all cases a $p$ value of $<0.05$ was regarded as significant. All children fed on optimised millet porridges recovered from wasting by the 6th week and being underweight by the 12th week, compared to 26 and 25 percent of children that were still wasted and underweight respectively among those fed on traditional millet porridges. Children fed on traditional millet porridge had their Height for Age (HAZ) scores deteriorate while those on optimised millet porridges had their HAZ scores improved. Diarrhoea incidences were significantly high among children fed on traditional millet porridge $(P=0.006)$. Fermented moringa and fermented pumpkin millet porridges can therefore be adopted as better options for complementary feeding among low socio-economic status households of Western Uganda.
\end{abstract}

Key words:Performance; nutritionally optimised;Complementary food; Low socioeconomic; Western Uganda.

\section{Background}

Infants and young children have high nutrient requirements due to rapid growth and development [1]. Globally, the period of complementary feeding continues to be a critical and most vulnerable period in the growth and development of children [2]. Malnutrition has for a long time been associated with poverty especially among children below 5 years [3, 4]. For most children from low socio-economic status households, malnutrition usually peaks at the time when complementary foods are introduced due to failure to access proper complementary foods [2, 5]. Current Demographic and Health Survey reports indicate stunting, underweight and wasting rates of 32,15 and 6 percent respectively among children below five years from the lowest wealth quintiles, compared to 17, 4 and 2 percent respectively for children from the highest wealth quintiles in Uganda [5]. Our baseline studies in Bujenje County of Western Uganda indicated that animal and fortified foods were less frequently and low viscosity millet porridges were the most common complementary foods [6]. Though millet porridge is reported as an abundant source of protein, iron, energy, calcium and zinc among households with low income [7], Its utilisation in human nutrition is influenced by its high bulky density, limited amino acids and high content of anti-nutrients such as phytates [8, 9]. For most households in Bujenje County, the inadequacies in millet porridge were exacerbated by the frequent occurrences of diarrhoea due to prolonged storage of prepared porridges at room temperature before it was fed to children [6]. Prominent use of traditional millet porridges combined with lack of knowledge, skills and complementary food technology to fight malnutrition can lead to an exacerbated malnourishment condition that may progress rapidly to severe acute malnutrition. The dietary management of moderate malnutrition should be based on the optimal use of locally available nutrient dense foods to improve on the nutritional status of children and prevent them from becoming clinically malnourished or failing to thrive $[10,11]$. Optimised millet porridges were developed by fermenting millet flours of either $17 \%$ pumpkin flesh powder or $7 \%$ moringa leaf powder as complementary food for children aged 7-24 months from the predominantly millet consuming households of Bujenje County in Masindi District. The porridges targeted not less than $60 \%$ of the daily energy, protein, iron, zinc and vitamin A requirements for children and inhibited growth of test pathogens of S. typhi, S. 
aureus, E. coli and S. Shiga due to their improved antimicrobial properties [12]. The performance of the nutritionally optimised millet porridges among severely malnourished children under rehabilitation in a hospital setting showed that they were 9297\% efficacious compared to F100, the hospital ration used for their treatment [13]. The objective of this study was therefore to determine the performance of these porridges on the nutritional status of moderately malnourished children. This was done using an integrated approach, as a prophylactic strategy for mitigating child malnutrition in Western Uganda. Mothers were involved in the production of their children's porridge flours and this was done to ensure sustainability of the technologies utilised.

\section{Methods}

The study was a closed cohort trial conducted over a period of 16 weeks. It was conducted from August 2013 to November 2013 in Bujenje County, Masindi District. Masindi District is located approximately 220 kilometres, by road west of Uganda's capital, Kampala. It was purposively selected since it is characterised by households with low income, high levels of infections and child malnutrition [14]. It is also associated with common use of millet porridges as a complimentary food for children [6]. Moderately malnourished children were recruited from Karongo, Kiryamyongo and Ntooma centres within Bujenje County. The children recruited from Ntooma centre were fed on traditional millet porridge as the control while those from Karongo and Kiryamyongo centres were fed on fermented millet porridge of either $7 \%$ moringa leaf powder or $17 \%$ pumpkin flesh powder respectively. Table 1 shows the composition of millet based porridge flours used in the intervention.

\begin{tabular}{|c|c|c|c|c|c|c|}
\hline Table 1: Composition of millet-based flours used in the intervention (Amounts/100g flour) \\
\hline Food type & Carbohydrates & Energy (k cal) & Protein (g) & Retinol ( $\mu$ g) & Iron (mg) & Zinc (mg) \\
\hline Traditional millet & $81.61 \pm 0.61$ & $396.86 \pm 0.85$ & $9.24 \pm 0.10$ & $0.001 \pm 0.0$ & $10.13 \pm 0.10$ & $2.15 \pm 0.10$ \\
\hline Moringa- millet & $79.61 \pm 0.3$ & $406.10 \pm 0.10$ & $10.37 \pm 0.30$ & $329.20 \pm 0.18$ & $17.99 \pm 0.4$ & $3.37 \pm 0.10$ \\
\hline Pumpkin-millet & $79.91 \pm 0.01$ & $396.28 \pm 0.10$ & $10.01 \pm 0.17$ & $312.8 \pm 0.08$ & $9.80 \pm 0.01$ & $2.01 \pm 0.01$ \\
\hline
\end{tabular}

\section{Sampling Procedure and Sample Size Determination}

Children from the two administrative locations of Bujenje County; namely Bwijanga and Budongo were purposively selected. Three out of nine parishes in Bujenje County were selected as recruitment centres. Their selection was based on the $\%$ prevalence of wasting among children aged 7-36 months as recorded in our previous studies (Unpublished results).

A sample size of 35 children per group was sufficient assuming a power of $80 \%$ basing on the percentage prevalence of Moderate Acute Malnutrition (MAM) nationally, reported at 3\% [15].

The Principal Investigator introduced the study project to the Local Council Chairpersons who connected her to the Voluntary Health Trainers attached to the three parishes of Ntooma, Kasongoire and Nyabyeya. Announcements were made in churches and villages inviting mothers/caretakers of children aged 7-36 months to bring their children for the screening exercise where a total of 93 children with their mothers/caretakers were recruited.

The inclusion criteria for the children in the study were as shown below:

- Aged 7 to 36 months.

- If aged 7-23 months, they should have been breastfeeding at the time of recruitment.

- Moderately wasted with MUAC of $\geq 11.5<12.5 \mathrm{~cm}$ (Yellow colour).
- A voluntary written consent form from a mother/caretaker.

- Absence of congenital abnormalities and reports of medical conditions such as tuberculosis and HIV (Human Immunodeficiency Virus).

- Using millet porridge as a complementary food.

\section{Methods of Data Collection and Assessment}

Prior to the study, 3 students offering a Bachelor of Science Degree in Human nutrition and Dietetics were trained to collect data. The training covered skills related to taking anthropometric measurements, carrying out dietary surveys and nutritional counselling.

Standing height/ length was taken using Short's Height Measuring Board (Short Productions, Woonsocket, RI) and recorded to the nearest $0.1 \mathrm{~cm} \mathrm{[16].} \mathrm{Age} \mathrm{was} \mathrm{determined} \mathrm{basing}$ on mothers/caretakers reports and verified using the child health clinic card. Body weight was taken using light weight-SECA mother-infant scales with a digital screen that were designed and manufactured under the guidance of United Nations Children Fund (UNICEF). All measurements were taken in duplicate with the children wearing light clothing and no shoes. Each measurement was taken by the same person to eliminate inter examiner error. Nutritional status indices for Height-For-Age (HAZ) and WeightFor-Age (WAZ) and Weight-For-Height (WHZ) were calculated using ENA for SMART 2010 software and interpreted using World Health Organisation (WHO) 2006 reference standards. 
A self administered questionnaire was used to collect data on the characteristics of study children and their households. Disease incidences among the study children were reported by mothers/caretakers.

\section{Characteristics of Study Children and their Households}

The characteristics of study children and their household members are shown in table 2 . They were not statistically different $(p>0.05)$.

Both female and male children with an average age range of 16-21 months were recruited. The children came from households which had 2-3 children aged less than 5 years. All recruited children were moderately wasted but their mean weight for the age $\mathrm{z}$ scores and mean height for age $\mathrm{z}$ scores were within the normal range ( $>-2 \mathrm{Z}$ scores).

Diarrhoea and malaria incidences occurring were the most reported sickness among these children. Only less than 50\% of the children were fully immunised, vitamin A supplemented and dewormed in the last 6 months. A good percentage of the recruited children had visited the health facility when sick and voluntary health trainers rendered treatment services for most of these children.

The average age range for the mothers/caretakers involved was 25-27 years and majority of them had low levels of education. Only a small percentage of the children' fathers had salaried form of employment. The mean total income per day for all households involved in the study was less than $\$ 2$.

Table 2: Baseline characteristics of children in the study and their households

\begin{tabular}{|c|c|c|c|c|}
\hline Variable & Traditional millet $\mathrm{N}=32$ & Moringa millet $\mathrm{N}=\mathbf{3 0}$ & Pumpkin millet $\mathrm{N}=31$ & P-value \\
\hline Male & $50 \%$ & $59.30 \%$ & $38.50 \%$ & NS \\
\hline Female & $50 \%$ & $40.70 \%$ & $61.50 \%$ & \\
\hline Age (Months) & $17.9 \pm 1.7$ & $19.2 \pm 1.7$ & $18.3 \pm 1.6$ & NS \\
\hline Number of children $<5$ years & $2.81 \pm 0.4$ & $2.51 \pm 0.3$ & $2.9 \pm 0.4$ & NS \\
\hline \multicolumn{5}{|l|}{ Nutritional status } \\
\hline WAZ & $-1.5 \pm 0.1$ & $-1.7 \pm 0.2$ & $-1.8 \pm 0.2$ & NS \\
\hline HAZ & $0.2 \pm 0.05$ & $-0.4 \pm 0.03$ & $-0.3 \pm 0.003$ & NS \\
\hline WHZ & $-2.3 \pm 0.09$ & $-2.2 \pm 0.09$ & $-2.2 \pm 0.06$ & NS \\
\hline \multicolumn{5}{|c|}{ Morbidity characteristics in last 2 weeks prior to the study } \\
\hline Diarrhoea & $77.00 \%$ & $74.60 \%$ & $76.90 \%$ & NS \\
\hline Malaria & $55.20 \%$ & $57.30 \%$ & $57.70 \%$ & NS \\
\hline Respiratory infections & $14.80 \%$ & $15.50 \%$ & $17.70 \%$ & NS \\
\hline \multicolumn{5}{|l|}{ Health care practices } \\
\hline Fully immunised & $12 \%$ & $14 \%$ & $12 \%$ & NS \\
\hline Vitamin A supplemented & $36.60 \%$ & $40.70 \%$ & $39.20 \%$ & NS \\
\hline De-wormed in last 6 months & 46.1 & 43.9 & 40 & NS \\
\hline $\begin{array}{l}\text { Visited a health facility when } \\
\text { sick }\end{array}$ & $80.40 \%$ & $90.10 \%$ & $86.90 \%$ & NS \\
\hline Maternal age & $26.5 \pm 1.6$ & $26.2 \pm 1.4$ & $26.1 \pm 1.1$ & NS \\
\hline \multicolumn{5}{|l|}{ Mother's education } \\
\hline No formal education & $7.70 \%$ & $18.50 \%$ & $3.80 \%$ & \\
\hline Primary & $80.80 \%$ & $70.40 \%$ & $88.50 \%$ & NS \\
\hline Secondary & $11.50 \%$ & $11.10 \%$ & $7.70 \%$ & \\
\hline \multicolumn{5}{|l|}{ Father's occupation } \\
\hline Salaried employment & $7.70 \%$ & $3.70 \%$ & $2.00 \%$ & \\
\hline No salaried employment & $87.60 \%$ & $92.60 \%$ & $90.30 \%$ & NS \\
\hline Not employed & $4.70 \%$ & $3.70 \%$ & $7.70 \%$ & \\
\hline Total family income per day & $\$ 0.1 \pm 0.02$ & $\$ 0.1 \pm 0.03$ & $\$ 0.1 \pm 0.03$ & NS \\
\hline
\end{tabular}




\section{Dietary Intake}

This was assessed on a weekly basis using repeated 24 hour recalls on non consecutive days. A list of all food items and drinks consumed in the last 24 hours was made by the trained Research Assistants. Food models and household measures assisted in recalling portion sizes of foods [17]. Amounts of kilocalorie, protein, vitamin $\mathrm{A}$, iron and zinc consumed from the 24 recall data were calculated using the East African Food Composition Tables and Nutri survey $[18,19]$. To validate the 24 hour recall data, calculation of usual nutrient intakes using actual intake obtained from 24 hour recall data was done [20].

\section{Production of Millet based Porridge Flours}

A month before the intervention, the Principal Investigator briefed three Voluntary Health Trainers on the project and its objectives. They were trained on the basic skills for the production of porridge flours and the method of preparing the porridges. Mothers/caretakers converged in the 3 agreed village centres for training. The production processes of cleaning, drying, grinding, blending and fermentation were carried out under the supervision and guidance of both the Voluntary Health Trainers and the Principal Investigator. Figure 1 shows the basic production processes followed.
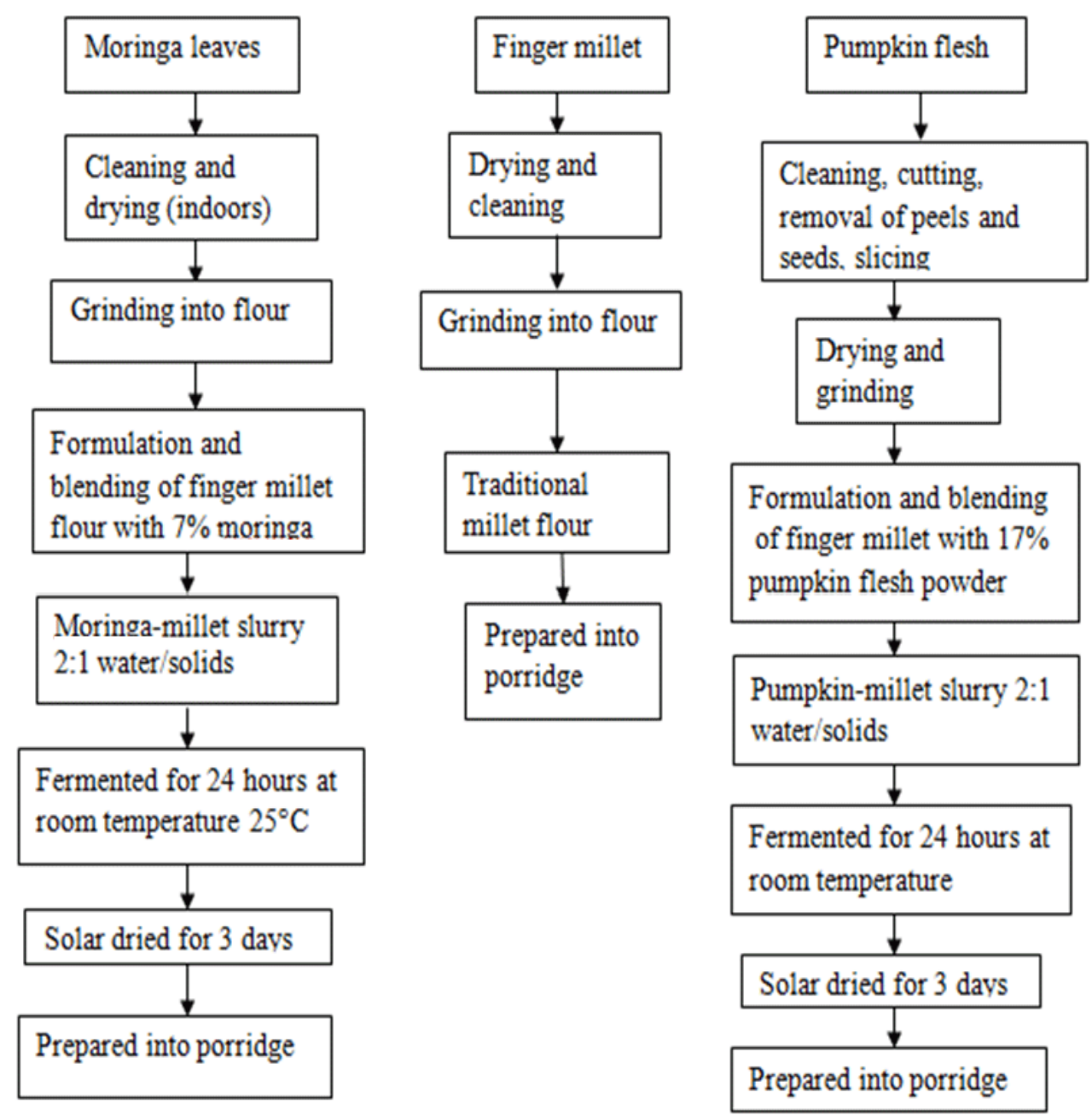

Figure 1: Production of moringa and pumpkin millet porridges dapted from [12]

\section{Preparation of Millet based Porridges}

Participatory demonstrations were conducted on the preparation of traditional millet porridges, fermented pumpkin millet and fermented moringa millet porridges from the three recruitment centres. Mothers prepared the porridges in groups of not more than 5 members based on the children's age and the type of porridge selected for the centre. The acceptability of fermented moringa and pumpkin millet porridges among mothers in Bujenje County had previously been assessed but mothers still tasted the prepared porridges to confirm their intake by their children [12]. Some types of porridge samples prepared during the participatory demonstrations were too thick and children could not ably take them. Consensus had to be made regarding the ratio of flour solids to water by explaining the implications 
of poor viscosity porridges to the nutrition of infants, and WHO recommendations regarding viscosity of porridges fed to children [21]. Hygiene during the preparation, cooking and serving of the porridges was encouraged by emphasizing the washing of hands, cooking and serving utensils with water and soap. Mothers were given standard cups for measuring the amount of porridges taken by children.

\section{Feeding Program for Children in the Study}

Table 3 shows the number of servings, amount of solids in each porridge serving and the amounts of porridge flours that were given to each mother/caretaker on a weekly basis. All children were fed porridges 4 times a day. The frequency of feeding or number of servings was governed by WHO recommendations [22]. To be able to meet the recommended nutrient intake for children aged 7-8 months, modifications had to be made on WHO recommendations for frequency of feeding. This change was based on the mothers/caretakers' experiences regarding amounts of porridges usually consumed at each serving. The amount of solid matter in the porridges varied from $15 \mathrm{~g}$ to $40 \mathrm{~g}$ in $150 \mathrm{mls}$ to $300 \mathrm{mls}$ of porridge depending on the age of the child and the type of porridge to be given. Porridge flours ranging from 1000-2000g were distributed weekly basing on the age of the child and the type of porridge the child was supposed to feed on. These amounts were calculated in such a way that they could cater for at least one additional child in a household since the average number of children less than five years in a household had been established as two.

\begin{tabular}{|c|c|c|c|}
\hline \multicolumn{2}{|c|}{ Table 3: Feeding program for the children in the study } \\
\hline Variable & $\begin{array}{c}\mathbf{7 - 8} \\
\text { months }\end{array}$ & $\begin{array}{c}\mathbf{9 - 2 4} \\
\text { months }\end{array}$ & $\begin{array}{c}\mathbf{2 5 - 3 6} \\
\text { months }\end{array}$ \\
\hline Serving & & & \\
\hline Number of servings & 4 & 4 & 4 \\
\hline Amount in a serving & $150 \mathrm{mls}$ & $200 \mathrm{mls}$ & $300 \mathrm{mls}$ \\
\hline
\end{tabular}

\begin{tabular}{|c|c|c|c|}
\hline \multicolumn{2}{|l|}{ Amount of solids per serving } & \multirow{2}{*}{} \\
\hline Traditional millet & $15 \mathrm{~g}$ & $20 \mathrm{~g}$ & $30 \mathrm{~g}$ \\
\hline Pumpkin millet & $18 \mathrm{~g}$ & $25 \mathrm{~g}$ & $35 \mathrm{~g}$ \\
\hline Moringa millet & $20 \mathrm{~g}$ & $30 \mathrm{~g}$ & $40 \mathrm{~g}$ \\
\hline
\end{tabular}

Amount of flour given per week

\begin{tabular}{|c|c|c|c|}
\hline Traditional millet & $1000 \mathrm{~g}$ & $1500 \mathrm{~g}$ & $2000 \mathrm{~g}$ \\
\hline Pumpkin millet & $1000 \mathrm{~g}$ & $1500 \mathrm{~g}$ & $2000 \mathrm{~g}$ \\
\hline Moringa millet & $1000 \mathrm{~g}$ & $1500 \mathrm{~g}$ & $2000 \mathrm{~g}$ \\
\hline
\end{tabular}

Mothers/caretakers reported to the centres to process the raw materials into porridges flours after every two weeks. The porridge flours produced were stored in sacks. They were distributed to mothers/caretakers on a weekly basis by a Voluntary Health Trainer attached to each centre. Research
Assistants carried out dietary assessments took anthropometric measurements and recorded reports of disease incidences weekly. They also emphasized the following key points to the mothers/caretakers:

- Breastfeeding children for not less than two years.

- Taking children for health days.

- Reporting disease incidences to the Voluntary Health Trainers (VHT's)/health centres.

- Giving porridges to children after breastfeeding

- Serving children other foods in addition to the porridges.

- Hygienic handling of children's food.

\section{Nutritional Performance of the Millet based Porridges}

Mothers/caretakers recorded the amounts of porridges consumed by children on daily basis. For illiterate mothers, one family member who could assist with taking records was identified. Voluntary Health Trainers monitored and supervised both the feeding and the keeping of records. Visits were also done to assess compliancy on the agreed recipe for the porridges, amounts of porridges taken daily and mothers experiences of feeding the porridges to children. Feeding trials were carried out for four months and during this period, incidences of diseases such as respiratory infections; malaria and diarrhoea episodes were recorded. The amounts of nutrients obtained from the ready to feed porridges were determined basing on their predetermined nutrient composition [13].

\section{Data processing}

Data was entered, cleaned and analyzed using SPSS (Statistical Package for Social Scientists) version 20.0 for windows (SPSS, Inc., Chicago IL). Mean prevalence of disease incidences and the mean HAZ scores were recorded. The percentage of children who were wasted and underweight were determined and compared over the 4 months period using Chi square tests. Analysis of variance in HAZ scores and nutrient intake were carried out using Post Hoc and differences among means were compared by Least Significant Difference (LSD) test. In all statistics, $\mathrm{p}<0.05$ was considered as significant.

\section{Results}

\section{Porridge Intake during the Study Period}

Records indicated that pumpkin millet porridge was the most consumed while traditional millet porridges were the least consumed by the children in the study. Fermented pumpkin and moringa millet porridges were therefore more palatable than traditional millet porridges (Figure 2)

\section{Nutrient Intake from the Millet Based Porridges}

For children still breastfeeding, the energy and protein intake per kilogram body weight was higher among children fed on moringa and pumpkin millet porridges than those fed on traditional millet porridge (Table 4). One way ANOVA with 


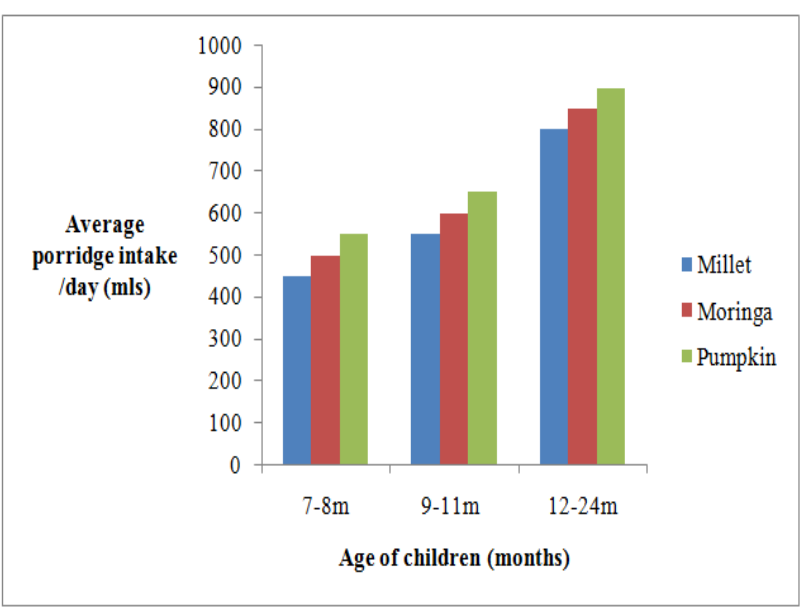

Figure 2: Average porridge intake among the children in the study

Table 4: Average kilocalorie and protein intake per kg body weight/ day for breastfeeding children

\begin{tabular}{|c|c|c|c|}
\hline Variable & $\begin{array}{c}7-8 \\
\text { months }\end{array}$ & $\begin{array}{c}9-11 \\
\text { months }\end{array}$ & $\begin{array}{c}12-23 \\
\text { months }\end{array}$ \\
\hline \multicolumn{4}{|c|}{ Kilocalorie intake/kg body weight/day } \\
\hline Traditional millet & 57.6 & 58 & 60.1 \\
\hline Pumpkin millet & 71.8 & 73.6 & 75.2 \\
\hline Moringa millet & 76.6 & 79 & 80.1 \\
\hline Recommended $^{*}$ & 83 & 89 & 86 \\
\hline \multicolumn{4}{|c|}{ Protein (g)/kg body weight/day } \\
\hline Traditional millet & 0.81 & 0.90 & 1.0 \\
\hline Pumpkin millet & 1.75 & 1.85 & 1.86 \\
\hline Moringa millet & 1.79 & 1.79 & 2.09 \\
\hline Recommended $^{*}$ & 1.0 & 0.87 & 0.87 \\
\hline
\end{tabular}

${ }^{*}$ Recommendation for children with a normal growth trend [45, 46].

post hoc multiple comparisons showed that children fed on traditional millet porridges had a significantly lower kilocalorie intake compared to those fed on fermented pumpkin millet porridge $(P=0.012)$ and fermented moringa millet porridge $(P$ $=0.024)$. The energy intake per kg body weight of children fed on fermented pumpkin millet and fermented moringa millet was not significantly different. Protein intake per kg body weight was also significantly lower among children fed on traditional millet porridges compared to those fed on fermented pumpkin millet $(P$ $=0.003)$ and fermented moringa millet $(P=0.009)$. The amount of protein intake was not significantly different among fermented pumpkin millet and fermented moringa millet fed groups. The kilocalorie intake per body weight for all children was below the recommended for children with a normal growth trend. In all age groups, the protein intake per kg body weight among fermented moringa and fermented pumpkin fed children groups were above the WHO recommendations for children with normal growth trend. Children aged 9-23 months who were fed on traditional millet porridges were also able to achieve the recommended protein intake per kg body weight/day for children with a normal growth trend.

Table 5 shows that the average daily kilocalorie, protein, iron, zincand vitamin Aintakes derived from traditional millet porridges were significantly lower than those derived from optimised millet porridges. A part from the kilocalorie requirements for children aged 25-36 months, optimised millet porridges were able to meet more than $60 \%$ of the nutrient requirements for children aged 7-36 months. Traditional millet porridges could not cater for vitamin A needs of children in the study. They also could not cater for more than $60 \%$ of the daily energy and zinc requirements for some children groups. The average daily nutrient intake from other foods was not significantly different among all groups of children, apart from the kilocalorie intake of children aged 13-24 months who were fed on fermented moringa millet $(P=0.043)$. The total average nutrient intake for children fed on traditional millet porridges was significantly lower compared to the total average nutrient intake for children fed on fermented pumpkin and fermented moringa millet porridges.

Optimised millet porridges have a better potential of catering for the energy, protein, vitamin A, iron and zinc requirements of children aged 7-36 compared to traditional millet porridges.

\section{Percentage Prevalence of Wasting during the Feeding Trials}

Figure 3 shows the percentage of wasted children from the time of recruitment to the end of the study period. All children recruited were moderately wasted at the beginning. The percentage of wasted children reduced very fast in the first 2 weeks. Wasting levels reduced slowly among children fed on traditional millet porridges compared to children fed on optimised millet porridges at $p=0.039$ in the 2 nd week and $p=$ 0.017 in the 4 th week. By the 6 th week, none of the children fed on fermented moringa and fermented pumpkin millet porridges was wasted, while $26 \%$ of the children fed on traditional millet porridges were still wasted $(P=0.002)$. By the end of the study, $7.2 \%$ of the children feeding on traditional millet porridges were still wasted while none of those fed on fermented moringa and fermented pumpkin millet porridges were wasted. There was no significant difference in the changes in wasting among children fed on fermented moringa and fermented pumpkin millet porridges.

Optimised millet porridges are therefore more effective in addressing wasting among children aged 7-36 months than traditional millet porridges.

\section{Trends in Underweight during the Study Period}

The percentage of children who were underweight from the start to the end of the study is shown in Figure 4. Fifty percent of children fed on optimised millet porridges and $40 \%$ of children fed on traditional millet porridges were underweight at the beginning of study. The percentage of underweight children in all groups reduced fast in the first four weeks. Though the prevalence of underweight among children fed on traditional millet porridge 
Performance of Nutritionally Optimised Millet Porridges as Complementary Food for Children from Low Socio-Economic Status Households in Bujenje County, Western Uganda

Table 5: Average daily nutrient intakes of children in the study compared to World Health Organisation recommendations

\begin{tabular}{|c|c|c|c|c|c|}
\hline Age groups & Energy & Protein & Vitamin A & Iron & zinc \\
\hline WHO, RNI (7-12months) & 300 k cal & $9.6 \mathrm{~g}$ & $300 \mu \mathrm{g}$ & $11 \mathrm{mg}$ & $2.8 \mathrm{mg}$ \\
\hline \multicolumn{6}{|l|}{ Nutrient intake ( Porridges) } \\
\hline Traditional millet group & $277.8 \pm 17.8(93 \%)$ & $6.5 \pm 0.4(67 \%)$ & $0(0 \%)$ & $7.2 \pm 0.5(66 \%)$ & $1.6 \pm 0.1(55 \%)$ \\
\hline Pumpkin millet group & $359.6 \pm 18.5(200 \%)$ & $8.8 \pm 0.7(92 \%)$ & $292.7 \pm 13.4(98 \%)$ & $8.4 \pm 0.7(77 \%)$ & $2.0 \pm 0.2(72 \%)$ \\
\hline Moringa millet group & $406.1 \pm 30.7(135 \%)$ & $10.4 \pm 0.8(108 \%)$ & $\begin{array}{c}329.2 \pm 24.9 \\
(110 \%)\end{array}$ & $18.0 \pm 1.4(164 \%)$ & $3.4 \pm 0.3(120 \%)$ \\
\hline P-value & 0.007 & 0.004 & $<.001$ & $<.001$ & $<.001$ \\
\hline \multicolumn{6}{|l|}{ Nutrient intake (Other foods) } \\
\hline Traditional millet group & $106.2 \pm 5.7$ & $2.0 \pm 0.3$ & $47.4 \pm 7.0$ & $2.0 \pm 0.3$ & $0.6 \pm 0.0$ \\
\hline Pumpkin millet group & $200.0 \pm 21.0$ & $2.1 \pm 0.3$ & $53.1 \pm 12.7$ & $2.1 \pm 0.3$ & $0.7 \pm 0.0$ \\
\hline Moringa millet group & $165.1 \pm 37.9$ & $2.0 \pm 0.3$ & $70.8 \pm 19.0$ & $2.3 \pm 0.3$ & $0.7 \pm 0.0$ \\
\hline P-value & 0.08 & 0.96 & 0.53 & 0.85 & 0.56 \\
\hline \multicolumn{6}{|l|}{ Total (Porridge \& Others) } \\
\hline Traditional millet group & $384.0 \pm 17.0$ & $8.5 \pm 0.7$ & $47.9 \pm 7.0$ & $9.3 \pm 0.7$ & $2.2 \pm 0.1$ \\
\hline Pumpkin millet group & $559.6 \pm 39.2$ & $10.9 \pm 1.0$ & $345.7 \pm 16.1$ & $10.5 \pm 0.9$ & $2.7 \pm 0.1$ \\
\hline Moringa millet group & $571.2 \pm 42.7$ & $12.4 \pm 1.1$ & $400 \pm 22.7$ & $20.2 \pm 1.5$ & $4.1 \pm 0.3$ \\
\hline P-value & .006 & .041 & $<.000$ & $<.000$ & $<.000$ \\
\hline WHO, RNI (13-24months) & $550 \mathrm{k} \mathrm{cal}$ & $10.9 \mathrm{~g}$ & $300 \mu \mathrm{g}$ & $11 \mathrm{mg}$ & $2.8 \mathrm{mg}$ \\
\hline \multicolumn{6}{|l|}{ Nutrient intake ( Porridges) } \\
\hline Traditional millet group & $317.5 \pm 0(58 \%)$ & $7.4 \pm 0.0(68 \%)$ & $0(0 \%)$ & $8.2 \pm 0.0(75 \%)$ & $1.7 \pm 0(61 \%)$ \\
\hline Pumpkin millet group & $396.1 \pm 0.4(72 \%)$ & $10.3 \pm 0.1(94 \%)$ & $323.3 \pm 2.5(108 \%)$ & $10.1 \pm 0.1(92 \%)$ & $2.4 \pm 0.1(86 \%)$ \\
\hline Moringa millet group & $487.3 \pm 0.0(89 \%)$ & $12.4 \pm 0.0(114 \%)$ & $395.0 \pm 0.0(132 \%)$ & $21.6 \pm 0.0(196 \%)$ & $4.0 \pm 0.0(144 \%)$ \\
\hline P-value & $<.001$ & $<.001$ & $<.001$ & $<.001$ & $<.001$ \\
\hline \multicolumn{6}{|l|}{ Nutrient intake (Other foods) } \\
\hline Traditional millet group & $217.2 \pm 19.7$ & $3.98 \pm 0.2$ & $140.0 \pm 13.4$ & $3.9 \pm 0.3$ & $0.61 \pm 0.0$ \\
\hline Pumpkin millet group & $233.7 \pm 4.7$ & $4.1 \pm 0.4$ & $138.10 \pm 17.1$ & $3.86 \pm 0.4$ & $0.58 \pm 0.1$ \\
\hline Moringa millet group & $185.68 \pm 10.85$ & $4.18 \pm 0.14$ & $115.12 \pm 14.0$ & $3.16 \pm 0.3$ & $0.62 \pm 0.0$ \\
\hline P-value & 0.043 & 0.924 & 0.397 & 0.159 & 0.49 \\
\hline \multicolumn{6}{|l|}{ Total (Porridge \& Others) } \\
\hline Traditional millet group & $534.7 \pm 19.7$ & $11.4 \pm 0.2$ & $139.9 \pm 13.4$ & $12.1 \pm 0.3$ & $2.4 \pm 0.1$ \\
\hline Pumpkin millet group & $629.7 \pm 5.1$ & $14.4 \pm 0.4$ & $461.4 \pm 17.9$ & $13.9 \pm 0.2$ & $3.0 \pm 0.1$ \\
\hline Moringa millet group & $673.00 \pm 10.85$ & $16.62 \pm 0.41$ & $510.16 \pm 13.96$ & $24.75 \pm 0.31$ & $4.6 \pm 0.1$ \\
\hline P-value & $<.001$ & $<.001$ & $<.001$ & $<.001$ & $<.001$ \\
\hline WHO, RNI (25-36 months) & $1150 \mathrm{k} \mathrm{cal}$ & $13 \mathrm{~g}$ & $300 \mu \mathrm{g}$ & $11 \mathrm{mg}$ & $3 \mathrm{mg}$ \\
\hline \multicolumn{6}{|l|}{ Nutrient intake ( Porridges) } \\
\hline Traditional millet group & $476.20+0.0(41 \%)$ & $11.09+0(85 \%)$ & $0(0 \%)$ & $12.36+0(112 \%)$ & $2.58+0(86 \%)$ \\
\hline Pumpkin millet group & $555.25+0.0(48 \%)$ & $14.21+0.0(109 \%)$ & $447.30+0(109 \%)$ & $13.87+0(126 \%)$ & $3.24+0(108 \%)$ \\
\hline Moringa millet group & $649.76+0.0(57 \%)$ & $16.59+0.0(128 \%)$ & $526.72+0(128 \%)$ & $28.78+0(262 \%)$ & $5.39+0(180 \%)$ \\
\hline P-value & $<.001$ & $<.001$ & $<.001$ & $<.001$ & $<.001$ \\
\hline \multicolumn{6}{|l|}{$\begin{array}{l}\text { Nutrient intake } \\
\text { (Other foods) }\end{array}$} \\
\hline Traditional millet group & $243.4 \pm 17.6$ & $6.2 \pm 0.2$ & $256.7 \pm 8.4$ & $4.1 \pm 0.3$ & $0.9 \pm 0.0$ \\
\hline
\end{tabular}


Performance of Nutritionally Optimised Millet Porridges as Complementary Food for Children from Low Socio-Economic Status Households in Bujenje County, Western Uganda

\begin{tabular}{|c|c|c|c|c|c|}
\hline Pumpkin millet group & $252.9 \pm 21.2$ & $5.3 \pm 0.6$ & $238.9 \pm 26.2$ & $4.1 \pm 0.3$ & $0.8 \pm 0.0$ \\
\hline Moringa millet group & $293.74 \pm 3.92$ & $6.38 \pm 0.28$ & $253.6 \pm 17.24$ & $3.7 \pm 0.7$ & $0.8 \pm 0.1$ \\
\hline P-value & 0.23 & 0.149 & 0.739 & 0.784 & 0.353 \\
\hline Total (Porridge \&Others) & & & & \\
\hline Children on Traditional millet & $719.6 \pm 17.6$ & $17.3 \pm 0.2$ & $256.7 \pm 8.4$ & $16.4 \pm 0.3$ & $3.5 \pm 0.0$ \\
\hline Children on Pumpkin millet & $808.2 \pm 21.2$ & $19.5 \pm 0.6$ & $686.3 \pm 26.2$ & $17.9 \pm 0.3$ & $4.1 \pm 0.03$ \\
\hline Children on Moringa millet & $943.5 \pm 3.9$ & $22.9 \pm 0.4$ & $780.2 \pm 17.4$ & $32.50 \pm 0.8$ & $6.21 \pm 0.1$ \\
\hline P-value & $<.001$ & $<.001$ & $<.001$ & $<.001$ & $<.001$ \\
\hline \multicolumn{2}{|r|}{} \\
\hline
\end{tabular}

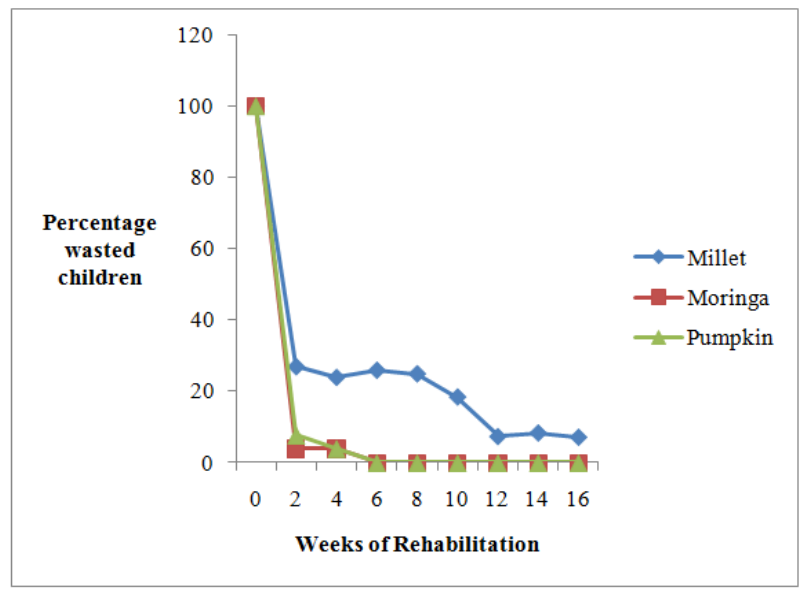

Figure 3: Percentage of wasted children during the study period

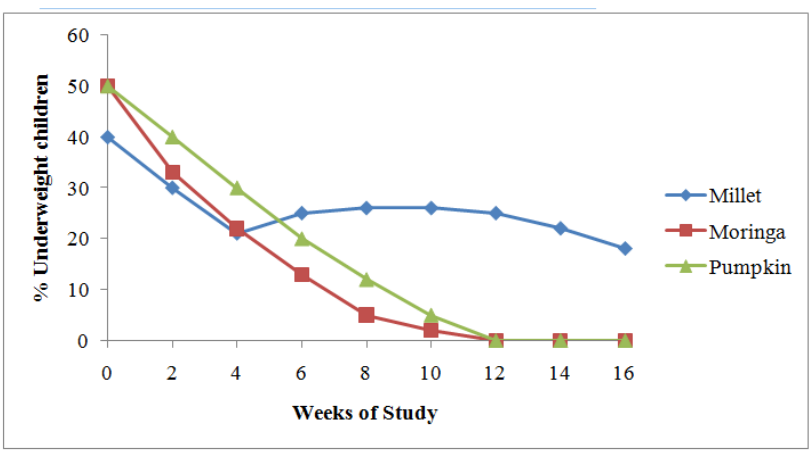

Figure 4: Percentage of underweight children during the study

also reduced in the beginning, the changes became inconsistent later on especially after the 4 th week, $\mathrm{P}=0.031$ in the 10 th week, and $P=0.007$ in the 12 th week. There was no significant difference between the percentages of underweight children among those fed on fermented moringa millet compared to those fed on fermented pumpkin millet porridges. By the 12th week, none of the children fed on fermented moringa and fermented pumpkin millet porridges was underweight while $25 \%$ of the children fed on the traditional millet porridge were still underweight. After the 12 th week, the percentage of children who were underweight among those fed on traditional millet porridges began to decline slightly up to the end of the study. About $20 \%$ of the children fed on the traditional millet porridge were still underweight at the end of the study period. Children fed on fermented moringa and fermented pumpkin millet porridges consistently recovered from being underweight unlike those fed on traditional millet porridges. Children fed on optimised millet porridges were able to recover from underweight faster than those fed on traditional millet porridges.

\section{Changes in HAZ Scores during the Study Period}

Figure 5 shows the HAZ scores of children from the time of recruitment to the end of the study. At the beginning of the study, all children recruited had their HAZ scores within the normal range. The mean HAZ scores for all study groups at the beginning were not statistically different $(P>0.05)$. They were -0.2 for children fed on traditional millet porridges, -0.4 for children fed on fermented moringa porridges and - 0.3 for children fed on fermented pumpkin millet porridges. Mean HAZ scores for children fed on fermented moringa and fermented pumpkin millet porridges gradually improved up to 1.4 and 1.0 HAZ scores respectively. Though the mean HAZ scores for children fed on the traditional millet porridges kept on fluctuating, they still remained within in the normal range $(\geq-2 S D)$.

By the 14th week of the study, children fed on traditional millet porridges had poorer HAZ scores compared to children fed on fermented moringa and fermented pumpkin millet porridges $P=0.007$. Children fed on moringa and pumpkin millet porridges had significantly better HAZ scores at the end of the study $P=$ 0.002 and 0.032 respectively. Fermented moringa and fermented pumpkin millet porridges can therefore prevent stunting among children.

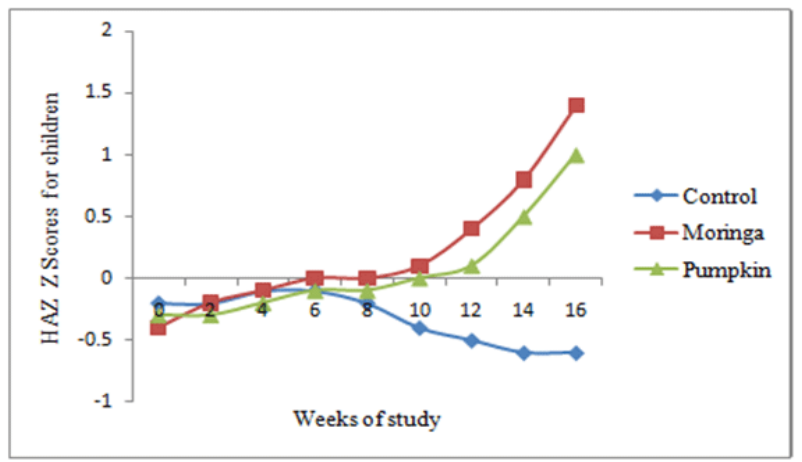

Figure 5: Changes in HAZ scores during the study period 


\section{Morbidity Patterns during the Study Period}

Table 6 shows disease incidences during the study period. Diarrhoea incidences were significantly high among children fed on traditional millet porridges $(P=0.006)$. Children fed on fermented moringa millet porridges also had significantly less reported incidences of respiratory infections $(P=0.003)$. Records from Voluntary Health Trainers showed that the health seeking habits of all groups were not significantly different. Majority of the children who had diarrhoea incidences were underweight and had poor height for age z scores at $P=0.01$ and 0.03 respectively. Optimised millet porridges are therefore capable of minimising diarrhoea incidences among children.

\begin{tabular}{|c|c|c|c|c|}
\hline \multicolumn{5}{|c|}{ Table 6: Mean prevalence of sickness during the study period } \\
\hline $\begin{array}{c}\text { Disease } \\
\text { condition }\end{array}$ & $\begin{array}{c}\text { Millet } \\
\text { porridge } \\
\mathbf{N}=\mathbf{3 2}\end{array}$ & $\begin{array}{c}\text { Moringa- } \\
\text { millet } \\
\text { porridge } \\
\mathbf{N}=\mathbf{3 0}\end{array}$ & $\begin{array}{c}\text { Pumpkin- } \\
\text { millet } \\
\text { porridge } \\
\mathbf{N}=\mathbf{3 1}\end{array}$ & P-value \\
\hline Diarrhoea & $5.9 \pm 0.93$ & $3.08 \pm 0.56$ & $2.9 \pm 0.61$ & 0.006 \\
\hline Malaria & $4.0 \pm 0.80$ & $3.8 \pm 0.61$ & $4.8 \pm 0.80$ & 0.646 \\
\hline $\begin{array}{c}\text { Respiratory } \\
\text { infections }\end{array}$ & $5.5 \pm 0.53$ & $3.6 \pm 0.38$ & $6.0 \pm 0.54$ & 0.003 \\
\hline
\end{tabular}

\section{Discussions}

\section{Intake of Porridges among Study Children}

Optimised millet porridges registered the highest average daily intake among the children in the study. Good acceptance of pumpkin flesh porridges has also been reported by some scholars $[12,23]$. This could be attributed to the common use of pumpkin flesh in this area as food, unlike moringa leaf powder which was mainly associated with herbal medicine for diarrhoea. The local breed of pumpkin flesh identified as "Okamanyaota" was very popular in this area. It has a lot of sugars, a quick turnover of 3-4 months, required minimal labour and could stay for 12 months without going bad. Better palatability of optimised millet porridges is also due to the flavour and taste contributed by fermentation [9].This had also been shown when carrying out sensory evaluation for the developed fermented moringa and fermented pumpkin millet porridges [12]. During fermentation, the produced lactic acid, alcohols and carboxylic acids promote a variety of flavours from the existing food resulting in improved flavour and taste [24]. Moringa leaves have got a bland taste which makes them easily take up the taste of foods they are combined. Though the colour of the leaves is green, the quantity of the leaf powder used was too small to have a discernable effect on the taste and colour of the porridges. The drying of moringa oleifera leaves condenses the nutrients so that a small quantity of leaves can be used without a discernible effect [25]. This concurs with findings by other researchers showing that moringa leaves were used successfully in other foods without negatively impacting the organoleptic properties $[25,26]$. Palatability of a novel food is essential to evaluate its potential use in strategies aimed at tackling a nutritional problem.

\section{Average daily Nutrient intake among Children in the Study}

The average daily nutrient intake from other foods consumed by children was not significantly different among all groups in the study. This was because the recruited children were from similar socio-economic characteristics, confirming the similarities in their feeding patterns. For children aged 13-24 months, the energy obtained from other foods consumed in addition to fermented moringa millet porridge was significantly different from that reported in children fed on fermented millet pumpkin and traditional millet porridges $(\mathrm{P}=0.043)$. Fermented moringa millet porridges were nutritionally superior among the porridges and so children could have got satisfied after taking it, leaving no room for other foods. Children were required to give priority to breast milk, followed by porridges and lastly other foods. This was done to encourage not only breastfeeding of children but also the intake of porridges since they were regarded to be nutritionally better than other foods consumed by children in the study. The average protein and kilocalorie intakes per body weight for breastfeeding children fed on optimised millet porridges were higher than for those fed on traditional millet porridges. Millet porridges have been reported to have low energy and nutrient density and this could account for the reduced nutrient intake [27]. The kilocalorie intake per kg body weight for all children was slightly less than the recommended for children with a normal growth pattern ( $>-2 \mathrm{Z}$ score). It was also less than the World Health Organisation recommendation of 150-220 k cal/kg body weight for severely malnourished children under rehabilitation [28]. A part from those children aged 7-8 months who were feeding on traditional millet porridges, the average protein intake per kg body weight for all breastfeeding children was higher than the recommended for children with a normal growth pattern. It was however less than the WHO's recommendation of 4-6g protein for severely malnourished children under rehabilitation [10]. With supervised feeding, traditional millet porridges can be able to meet the nutrient requirements for some children especially iron. The superior value of millet compared to other cereals has been highlighted by other researchers and should be utilised to a maximum by children from low socio economic status households [7, 27]. Children fed on traditional millet porridges had challenges in meeting their vitamin A requirements due to deficiencies of vitamin A in millet [12]. This relates well with studies by Bhaskaracharya (2001) where millet is reported as a poor source of $\beta$ - carotene [27]. Some children fed on traditional millet porridges had also challenges in meeting their energy and zinc requirements. The bulkiness of millet porridges, high nutrient requirements for this age group together with the limited gastric capacity for children at this age could account for this nutritional gap. Since children at this age have a high growth velocity, energy and nutrient needs there is need to enrich this most nutritious and abundant cereal especially for children from 
low socio economic status households who cannot afford animal foods and supplements [23]. According to WHO, deficiencies in iron, vitamin A and zinc rank among the ten leading causes of morbidity, disability and death among children from developing countries [29]. Deficiencies in micronutrients at this stage can lead to irreversible mental and physical development and therefore need to be addressed [30]. Though some children fed on traditional millet porridges met their protein, iron and zinc requirements, findings indicate that millet contains a high concentration of inhibitors like tannins and phytates that affect bioavailability of iron and zinc, and digestibility of starch and protein $[9,31]$. The total average iron and zinc intake from children fed on fermented pumpkin millet porridges was slightly below WHO's recommendations. However they still had better intakes compared to children fed on traditional millet porridges. The role played by fermentation in improving the bioavailability of iron and zinc and digestibility of protein and starch also places fermented moringa and pumpkin millet porridges in a better position compared to traditional millet porridges [9, 31, 32]. The amount of nutrients derived from optimised millet porridges were in some cases lower than the recommended but fulfilled the study design target of meeting at least $60 \%$ of the daily Recommended Nutrient Intake (RNI). For children aged 25-36 months, all porridges could not meet $60 \%$ of the daily energy requirements. The porridges had been designed as complementary food for children aged 7-24 months [13]. The frequency of feeding on the porridges may also need to be adjusted for children above 24 months.

Both moringa leaves and pumpkin flesh powders improved the nutritional value of millet porridges. This is supported by laboratory tests for their nutrient composition and research findings by other scholars $[8,33]$. Optimised millet porridges had a negative impact on gelatinisation. This allowed for more solid matter to be used, further enriching the porridges. Poor gelatinisation properties of pumpkin enriched porridges have also been reported by Usha and Lakshmi $(2,000)$. This helps to enrich the nutrient content of porridges without affecting their viscosity and is very important for infants who find it hard to digest thick porridges. Though fermented pumpkin millet porridges were nutritionally inferior to fermented moringa millet porridges, the nutrient intakes for children feeding on them was not significantly different because of their better palatability compared to fermented moringa millet porridges.

\section{Effect of Optimised Millet Porridges on the Nutritional Status of Moderately Malnourished Children}

Nutritional status of study children improved significantly after being treated with supplemental porridges. Reduction in wasting and underweight, and improvements in HAZ scores after feeding with fermented moringa and fermented pumpkin millet porridges demonstrate how simple technologies like fermentation combined with bio fortification with nutrient rich locally available food materials can improve children nutritional status. Wasting levels reduced earlier than underweight levels since wasting is normally caused by current inadequacies in food intake and or diseases and it responds very fast to treatment [26]. Underweight takes into account both chronic and acute forms and responded after a slightly longer time compared to wasting. The percentage prevalence of underweight among children fed on the traditional millet porridge kept on fluctuating and was influenced by diarrhoea incidences. This study finding is comparable to a study in South Africa where WAZ scores failed to improve when moderately wasted children were fed for 3 months on thickened porridges with added sugar and oil [34]. Successful reports among children in this study can be attributed to both fermentation and the blending of millet porridges flours with nutrient rich plant foods like moringa leaf powder and pumpkin flesh powders. Fermentation has been reported to improve on both the digestibility of starch and protein and the bioavailability of iron and zinc which greatly contribute to good nutritional status [9, 31, 35]. Both moringa oleifera leaves and pumpkin flesh powders are locally available resources that bridged the nutritional value in millet by providing children with high carotene content $[8,36]$. Improved vitamin A intake has been reported to reduce infections in children [30]. The reported high quality and easily digested protein in moringa leaves and the enriched nutrients through supplementation with the pumpkin flesh, all contributed to the improved available proteins which are key for not only growth but also increased immunity in children $[37,26]$.

Both lactic acid fermentation and moringa leaf powder have been shown to be effective in the fight against malnutrition. Fermented yellow maize and millet supplemented with moringa oleifera powder have been shown to have the potential of improving the nutritional status by curbing Protein Energy Malnutrition [38]. Fermentation of moringa oleifera leaf powders combined with yellow maize (Zea mays) and soybean (Glycine max) blend has also been reported to improve weight and length in infants aged 6-12 months [32].

\section{Effect of Optimised Millet Porridges on the Morbidity Status of Moderately Malnourished Children}

Diarrhoeal infections were common among children feeding on traditional millet porridges compared to those feeding on optimised millet porridges. Much as this age group is vulnerable to infections like diarrhoea, the habit of leaving prepared porridges for long before being given to children was common in this county and must have contributed to the high diarrhoea incidences [30]. Various studies have reported the probiotic potential of fermentation as far as dealing with diarrhoeal infections in children is concerned. Efficient lactic acid fermentation produces a pH of 4 or less at which growth of bacteria pathogens is inhibited $[9,24,39]$. Our previous studies also showed fermented moringa and fermented pumpkin millet porridges to have inhibited E.coli, S. aureus, S. shiga and S. Typhi pathogens [12]. Such a property of nutritionally optimised millet porridges placed the children fed on them in a better position compared to those fed on traditional millet porridges. Reduced incidences of respiratory infections 
among children feeding on fermented moringa millet porridge could be due to the special attributes of moringa leaves. Moringa oleifera leaves have been reported to contain complex chemical compounds with antibiotic and antioxidant properties that can boost the body's natural immune system and help alleviate a host of ailments $[36,40]$. The results can also be compared to an interventional study in Burkina Faso where using 10g moringa oleifera leaves powder as a supplement in porridges resulted in reduced diarrhoea episodes of $7.8 \%$ against the control of 80.3\% without moringa supplement [26]. Results in this study support the fact that functional foods with good amounts of micronutrients and phytochemical compounds can be developed with beneficial impact on health and nutrition among children [41]. Majority of children with diarrhoea incidences tended to have poor height for age $\mathrm{z}$ scores and weight for age $\mathrm{z}$ scores. This is because diarrhoea affects linear growth resulting in persistent stunting [30]. Diarrhoea in Uganda is associated with a decrease in dietary intake of $40-50 \%$ for energy and protein intakes and this impacts weight negatively [30].

Optimised millet porridges improved the nutritional status by not only providing an enhanced source of nutrients but also minimising diarrhoea incidences. This concurs with the UNICEF Conceptual Framework where inadequate dietary intake and disease are both shown as immediate causes of malnutrition and death [30].

\section{Technology Uptake by Mothers/Caretakers}

The raw materials used for the production of millet porridge flours were locally available and this motivated mothers in learning about the technologies involved. Judicious blending of locally available raw materials has been encouraged in many low socioeconomic status households as a strategy for improving the nutritional value of plant based complementary foods [42]. Mothers/caretakers were involved in the processing of their own porridges and feeding them to their children. The technologies involved in the production of the nutritionally optimised millet porridges were thus fully understood. Mothers were able to practically demonstrate how they can utilise the technologies learnt to process and prepare the new porridges for their children. The monitoring of children's progress and the comparisons done with other children in the centre encouraged many mothers to exploit the technologies taught for the good of their children. This provided a solution to not only the high diarrhoea incidences but also the poor nutritional status among the children in the study. However, during the rainy seasons, there was a challenge of drying the porridge flours using the sunshine. Provision of affordable better forms of drying such as solar driers, might be necessary to ensure that the technologies learnt are fully integrated in the livelihoods of communities.

\section{Conclusions}

Fermented moringa and pumpkin millet porridges were able to rehabilitate moderately malnourished children by improving the nutritional status as determined by wasting, underweight and stunting within a period of 4 months. Through involvement of mothers/caretakers, the technology for the production of optimised millet porridges was transferred to mothers/caretakers as part of the strategies to address child malnutrition in Bujenje County of Western Uganda. Optimised millet porridges can therefore be adopted by mothers/caretakers as better complementary foods in predominantly millet consuming communities of Western Uganda. This could provide a sustainable solution to the child malnutrition problem that is attributed to lack of proper complementary foods and infections like diarrhoea.

\section{Acknowledgements}

Kyambogo University found in Uganda is hereby acknowledged for funding this project. The authors would also like to thank the parents/caretakers of the study children for willingly participating in this study and the field assistants who diligently collected the data.

\section{Declarations \\ Conflict of interest}

The authors declare that they have no competing interests.

\section{Ethics approval and consent to participate}

The design and ethics of the study were reviewed and cleared by The Aids Support Organisation (TASO) internal review board (TASOIRC/029/13-UG-IRC-009), and then approved by the Uganda National Council of Science and Technology (HS 1315). Informed consent from the mothers/caregivers of the study children was given by signing a form.

\section{Clinical trial registration}

The Aids Support Organisation (TASO) internal review board ethical committee approved the study and registered it as TASOIRC/029/13-UG-IRC-009. The Uganda National Council of Science and Technology gave clearance on $13^{\text {th }}$ January 2014.

\section{References}

1. Aemro $\mathrm{M}$, et al. Dietary diversity and meal frequency practices among infant and young children Aged 6-23 months in Ethiopia: A secondary analysis of Ethiopian demographic and health survey 2011. Journal of nutrition and metabolism. 2013; 2013.

2. Victora CG, et al. Worldwide timing of growth faltering: revisiting implications for interventions. Pediatrics. 2010; 125(3):e473-80. doi: 10.1542/peds.2009-1519

3. Hossain MI, MA Wahed, and S Ahmed. Increased food intake after the addition of amylase-rich flour to supplementary food for malnourished children in rural communities of Bangladesh. Food Nutr Bull. 2005;26(4):323-329.

4. Black RE, et al. Maternal and child under nutrition: Global and regional exposures and health consequences. The lancet. 2008;371:243-260.

5. UBOS and ICF. Uganda Demographic and Health Survey 2016: Key Indicators Report. 2017,UBOS and ICF: Kampala, Uganda: UBOS, and Rockville, Maryland, USA. 
6. Isingoma BE, Samuel M, Edward K, Maina GW. Socioeconomic and Demographic Factors Influencing Feeding Practices, Morbidity Status, and Dietary Intakes of Children Aged 7-24 Months in Rural Uganda. Ecol Food Nutr. 2017;56(1):1-16. doi: 10.1080/03670244.2016.1246360

7. Obilana AB. "Overview: Importance of Millets in Africa." AFRIPRO, Workshop on the Proteins of Sorghum and Millets: Enhancing Nutritional and Functional Properties for Africa Paper 02, 2003.

8. Usha R, M Lakshmi, Ranjani M. Nutritional, Sensory and Physical Analysis of Pumpkin Flour Incorporated into weaning Mix. Mal JNutr. 2010;16(3):379-387

9. Lei V. Probiotic potential of African fermented millet. Food microbiology Department Food Science. Frederiksberg-Denmark., in Food Science2006, The Royal Veterinary and Agricultural University: Denmark.

10. Ashworth A, E Ferguson. Dietary counseling in the management of moderate malnourishment in children. Food Nutr Bull. 2009;30(3 Suppl):S405-433.

11. Ijarotim SO, F Aronge. Evaluation of nutritional composition, sensory and physical properties of a potential weaning food from locally available food materials-bread fruit (artocarpus altilis) and Soya bean (glycine max). Pol J Food Nutr Sci. 2005; 14(55):411-415.

12. Isingoma BE, et al. Improving the nutritional value of traditional finger millet porridges for children aged 7-24 months in Bujenje County of Western Uganda. African Journal of Food Science. 2015;9(8):426-436.

13. Isingoma BE, et al. Performance of Nutritionally Optimized Millet Porridges in the Rehabilitation of Severely Malnourished Children at Mulago National Referral Hospital, Uganda. British Journal of Medicine \& Medical Research. 2016;18(2):1-12.

14. Ring U, S Develo. Masindi District Local Government. 2009.

15.UBOS and ICF. Uganda Demographic and Health Survey, 2011/2012, Kampala, Uganda: UBOS and Calverton, Maryland: ICF International Inc.

16.Lohman T, A Roche, and R Martorell, eds. Anthropometric standardisation. Reference manual. 1998: Champagne IL: Human Kinetics Books.

17.Gibson, R.S. and E.L. Ferguson, An interactive 24-hour recall for assessing the adequacy of iron and zinc intakes in developing countries. Washington, DC: International Life Sciences Institute, 2008.

18. West, C., et al., Food composition table for energy and eight important nutrients in foods commonly eaten in East Africa. CTA/ECSA, Ede, 1987.

19.Juergen E, et al. Emergency Nutrition Assessment, 7th June 2010.

20. Pereira RA, Araujo MC, Lopes Tde S, Yokoo EM, et al. How many 24hour recalls or food records are required to estimate usual energy and nutrient intake? Cad Saude Publica. 2010;26(11):2101-2111.

21. Mouquet C, Greffeuille V, Treche S. Characterization of the consistency of gruels consumed by infants in developing countries: assessment of the Bostwick consistometer and comparison with viscosity measurements and sensory perception. Int J Food Sci Nutr. 2006;57 (78):459-469. DOI: $10.1080 / 09637480600931618$

22. Dewey KG, KH Brown. Update on technical issues concerning complementary feeding of young children in developing countries and implications for intervention programs. Food Nutr Bull. 2003;24(1):528. DOI: $10.1177 / 156482650302400102$
23. Compaore W, et al. Nutritional properties of enriched local complementary flours. Advance Journal of Food Science and Technology. 2011;3(1):31-39.

24. Blandino A, et al. Cereal-based fermented foods and beverages. Food Research International. 2003;36(6):527-543.

25. Fuglie LJ. The miracle Tree: Moringa oleifera, Natural Nutrition for the Tropics. 2005, Dakar, Senegal: Church World Service.

26.Zongo U, et al. Nutritional and Clinical Rehabilitation of Severely Malnourished Children with Moringa oleifera Lam. Leaf Powder in Ouagadougou (Burkina Faso). Food and Nutrition Sciences. 2013;4(9):991-997.

27. Singh P, RS Raghuvanshi. Finger millet for food and nutritional security. African Journal of Food Science. 2012;6(4):77-84.

28. Ashworth, A. Guidelines for the inpatient treatment of severely malnourished children 2003, World Health Organisation library cataloguing-in-Publication data.

29. Ruel MT, Menon P, Loechl C, Pelto G. Donated fortified cereal blends improve the nutrient density of traditional complementary foods in Haiti but iron and zinc gaps remain for infants. Food Nutr Bull. 2004;25(4):361-376. DOI: 10.1177/156482650402500406

30. FANTA-2. The Analysis of the Nutrition Situation in Uganda. Food and Nutrition Technical Assistance II Project (FANTA-2), 2010, AED Washington, DC.

31.Calvin Onyango, Horst Noetzold, Annette Ziems, Thea Hofmann, Thomas Bley, Thomas Henle. Digestibility and anti nutrient properties of acidified and extruded maize-finger millet blend in the production of uji. LWT- Food science and Technology. 2005;38(7):697-707.

32. Odinakachukwu ICIN, et al. Development and nutritional evaluation of infant complementary food from maize (Zea mays), soybean (Glycine max) and Moringa oleifera leaves. International Journal of Nutrition and Food Sciences. 2014;3(4):290-299.

33. Thurber MD, JW Fahey. Adoption of Moringa oleifera to combat under-nutrition viewed through the lens of the "Diffusion of Innovations" theory. Ecol Food Nutr. 2009;48(3): 212-225. doi: $10.1080 / 03670240902794598$

34. Glatthaar I, et al. Protein-energy malnutrition: the role of nutrition education in rehabilitation. Human nutrition. Clinical nutrition. 1986;40(4):271-285.

35. Thierry NN, et al. Effect of Pure Culture fermentation on biochemical composition of moringa oleifera Lam leaves powders. Food and Nutrition Sciences. 2013;4(8):851-859.

36. Fahey JW. Moringa oleifera: A Review of the Medical Evidence for Its Nutritional, Therapeutic, and Prophylactic Properties. Part 1. Trees for Life Journal. 2005;1(5):1-15.

37. Aleknaviciene P, et al. Amino acid profile of organically grown alternative agricultural products. Agronomy Research. 2009. 7(2):565571.

38. AK Arise, RO Arise, MO Sanusi, OT Esan, SA Oyeyinka. Effect of Moringa oleifera flower fortification on the nutritional quality and sensory properties of weaning food. Croat. J. Food Sci. Technol. 2014;6(2):6571.

39. Guslandi M. Antibiotics for inflammatory bowel disease: do they work? Eur J Gastroenterol Hepatol. 2005;17(2):145-147. 
40.Kumar NA, L Pari. Antioxidant action of Moringa oleifera Lam (drumstick against vantitubercular drugs induced lipid peroxidation in rats. Journal of Medicine Food. 2003;6(3):255-259.

41.Yang RY, et al. "Propriétés Nutritionnelles et Fonctionnelles des Feuilles de Moringa; Du Germoplasme, à la Plante, à l'aliment et à la santé," 2006: Virginie Levasseur The World Vegetable Center, 2006.

42.Lombor, TT, EJ Umoh, E Olakumi. Proximate Composition and Organoleptic Properties of Complementary Food Formulated from Millet (Pennisetum psychostachynum), Soyabeans (Glycine max) and Crayfish (Euastaeus spp). Pakistan Journal of Nutrition. 2009;8(10):1676-1679.
43. Dalmau J, Peña-Quintana L, Moráis A, Martínez V, Varea V, Martínez MJ. et al. Quantitative analysis of nutrient intake in children under 3 years old. ALSALMA study. An Pediatr (Barc). 2015;82(4):255-266. doi: 10.1016/j.anpedi.2014.09.017

44 Dewey K, K Brown. Update on technical issues concerning complementary feeding of young children in developing countries and implications for interventional programs. Food and Nutr Bull, in press, 2002.

45. Dewey K. Guiding principles for complementary feeding of the breastfed child. 2003. 